\title{
Empiirinen analyysi EU:n ja Kiinan välisestä maatalouskaupasta - mikä selittää Kiinan kasvavaa elintarviketuontia?
}

\author{
Jyrki Niemi ${ }^{1}$ ja Ellen Huan-Niemi ${ }^{1}$ \\ ${ }^{I}$ MTT Taloustutkimus, Luutnantintie 13,FI-00410 Helsinki,jyrki.niemi@mtt.fi
}

\section{Tiivistelmä}

Kiina on kasvamassa kovaa vauhtia yhdeksi maailman suurimmista ja tuottoisimmista elintarvikemarkkinoista. Kiinan 1,3 miljardin ihmisen tulotason noustessa ja kaupungistumisen edistyessä, kysyntä laadukkaita, terveellisiä ja ympäristöystävällisiä tuotteita kohtaan lisääntyy. Kiinan kotimainen tuotanto ei kykene vastaamaan lisääntyvän ravinnon kulutuksen ja ruokavalioiden koostumuksen huomattaviin muutoksiin. Kiinan luonnonvarat ovat jo tällä hetkellä varsin kovalla koetuksella veden puutteen ja maaperän köyhtymisen takia.

Tässä tutkimuksessa analysoidaan Kiinan kasvavaa maataloustuotteiden ja elintarvikkeiden tuontia suhteessa tulojen kasvuun, tuontihintojen muutoksiin sekä Kiinan kaupan vapautumisesta seuranneisiin tullien alentamiseen. Tutkimus tarkastelee erityisesti Kiinan ja EU:n välisten kauppasuhteiden kehitystä hyödyntämällä FAO:n kauppatilastoja vuosilta 1986 - 2005. Kauppavirtoja kuvaavat ekonometriset mallit on rakennettu tutkimuksessa kuudelle EU:sta Kiinaan viedylle maataloustuotteelle: pakastettu sianliha, pakastekala, hera, ohra, olut ja viini.

Tutkimuksen teoreettisessa osassa muodostetaan kaupan volyymiä selittävät kysyntämallit, jotka estimoidaan tutkimuksen empiirisessä osassa. Tutkimuksen teoreettisena pohjana on oletus epätäydellisestä kilpailusta, joka on seurausta siitä, että kilpailevat tuotteet ovat epätäydellisiä substituutteja. Maahantuojan ostopäätöksiin vaikuttavista tekijöistä tuotteen hinta on usein tärkein tekijä, mutta tuoja ei silti välttämättä osta kaikkia maataloustuotteitaan edullisimmalta tavarantoimittajalta. Muutkin tekijät vaikuttavat maataloustuotteiden kauppavirtoihin. Näitä tekijöitä ovat laadulliset ominaisuudet - tuotteen imago (ylellisyystavarat), tuotenimet ja kulttuuritausta (markkinointi), laatu, toimitusaika, toimitusten luotettavuus, pakkaus - sekä vallitsevat kauppasuhteet (esim. kulttuuriset, historialliset tai poliittiset siteet kaupantekijöiden välillä).

Estimoinneista saadut tulokset osoittavat Kiinan maataloustuotteiden ja elintarvikkeiden tuontikysynnän reagoineen varsin voimakkaasti reaalitulojen muutokseen, mutta olleen melko joustamatonta suhteessa reaalihintojen muutoksiin. Kiinalaiset maahantuojat ovat kuitenkin herkkiä reagoimaan tuontituotteiden suhteellisiin hintamuutoksiin eli hintakilpailukyky vaikuttaa merkittävästi viejän markkinaosuuteen Kiinassa. Kiinalaiset maahantuojat etsivät halvempia tuotevaihtoehtoja, mikä johtaa ulkomaisten tavarantoimittajien väliseen kiivaaseen hintakilpailuun. Tulokset tukevatkin päätelmiä, joiden mukaan Kiinan markkinoilla hintakilpailuun osallistuvat EU-yhtiöt joutuvat siirtämään tuotantonsa Kiinaan ollakseen kustannustehokkaita.

Kiinan WTO-jäsenyys sekä käynnissä oleva tiiviimpi integraatio maailmantalouteen tarjoavat tulevaisuudessa monenlaisia mahdollisuuksia ja haasteita eurooppalaisille elintarvikeyrityksille. Tämän tutkimuksen mukaan tullien alentamisella ei ole suurta merkitystä EU-viennin määrään Kiinaan. Kiinalaisten kuluttajien ostovoiman kasvu on merkittävin selittävä tekijä Kiinaan tuotavien maataloustuotteiden ja elintarvikkeiden kysynnän lisääntymisessä - sekä lyhyellä että pitkällä aikavälillä. On odotettavissa, että taloudellisen kasvun jatkuessa maataloustuotteiden ja elintarvikkeiden tuonti Kiinan markkinoille kasvaa entisestään.

Asiasanat: EU, Kiina, ekonometriset mallit, vienti, maataloustuotteet, tulot, tuontihinnat, tuontitullit 


\title{
Empirical analysis of China's growing agricultural imports from the EU
}

\author{
Jyrki Niemi ${ }^{1}$ and Ellen Huan-Niemi ${ }^{1}$ \\ ${ }^{I}$ MTT Economic Research, Luutnantintie 13,FI-00410 Helsinki,ellen.huan-.niemi@mtt.fi
}

\section{Introduction}

The economic emergence of the world's most populous nation is having a mesmerising effect on exporters from the western world. China is on course to overtake Germany as the third largest economy in the world, just behind the United States (US) and Japan. China is turning into one of the world's largest and most lucrative food markets. As the incomes of China's 1.3 billion people and urbanisation rates continue to rise, demand for quality, health and environment conscious food products will escalate. Domestic production will eventually be unable to meet the exponential growth in demand due to rising food consumption, marked changes in the composition of diets and continued stress on China's natural resources due to water scarcity and land degradation.

Previously, China had been a significant net exporter of agricultural products, but since 2003 the imports of agricultural products have exceeded exports. China is now a major net importer of agricultural products. The Chinese food market is considered as one of the most dynamic and promising food markets for EU agricultural exports. Given China's enormous size and catch-up potential, Colby et al. (2000) indicated that freer trade after China's WTO accession would substantially expand Chinese demand for food products. Schmidhuber (2001) argued that sharp tariff reductions will make EU exports competitive in China's market not only on quality basis but also in price, thus stimulating consumer demand for imported goods. China's middle class is expected to number 150 million by 2010. This means new opportunities for EU exporters in the growing processed and high-value food market, mainly in busy urban areas because of convenience, healthier choices, variation and quality. The Chinese market for high-value consumer goods is estimated to be worth 1 trillion euros by 2010 (DG Trade 2007a).

The EU and China are two of the biggest markets in the world, and both are actively trading with each other. In 2006, China remained the EU's second largest trading partner right behind the US, whereas the EU continued in its role as China's first trading partner ahead of both the US and Japan. The EU enjoyed a trade surplus with China at the beginning of the $1980 \mathrm{~s}$, but now the EU is experiencing a sizeable widening deficit with China from $€ 51$ billion in 2001 to $€ 128$ billion in 2006, representing EU's largest bilateral trade deficit (DG Trade 2006).

China is increasingly becoming an important destination for EU agricultural exporters even though the EU is having an agricultural trade deficit with China. In 2005, EU-15 agricultural exports (including seafood) reached $€ 956$ million (USD 1,214 million), $€ 416$ million or $77 \%$ more than the 2001 level. The growth in EU exports to China has increased from an averaged 4.6\% per year in the period 1990-2000 to an averaged 14.3\% per year in the period 2001-2005. The EU will see its agricultural exports to China exceed $€ 2$ billion in five years, if current trade trends continue. EU's agricultural exports are likely to hit $€ 4$ billion, when China's urban middle class reaches 200 to 250 million (People's Daily 2006). Booming middle class income levels have fuelled most of the country's increased appetite for imported food products and their tastes are expanding to include more westernstyle foods as more people become more affluent. From 2001 to 2005, the value of wines exported from EU to China rose from $€ 12$ million to $€ 36$ million, virgin olive oil grew from $€ 500,000$ to $€ 8.4$ million, cheese exports jumped from $€ 500,000$ to $€ 2.7$ million, and exports of processed agricultural products increased from $€ 110$ million to $€ 206$ million (People's Daily 2006). More than $90 \%$ of the agricultural trade with China used to be concentrated in raw products. It is worthy of note that the share of raw materials in EU exports is declining fast, and that value added goods are showing a high growth rate as China's buying power increases.

This paper examines China's agricultural imports in regard to income growth, import price changes, and tariff reductions due to China's trade liberalisation. Many studies have estimated the effect of trade policy on agriculture with aggregated commodities, but this paper examines the effect of trade liberalisation on specific food products: frozen pigmeat, frozen fish, whey, barley, beer, and wine. More specifically, this paper attempts to model behavioural relationships in the agricultural trade 
between China and the EU by considering three issues in detail. The first is the long-term relationship between the growth rate of agricultural imports and the rate of income growth in China. The second issue concerns the effects of tariff reductions on China's agricultural imports from the EU and globally. The third issue concerns EU exporters' capacity to influence their market shares. This depends on product heterogeneity, which would suggest that EU can alter China's agricultural imports from the EU through relative-price changes.

\section{Methodology and Data}

Imperfect competition arising from product differentiation underlies the theoretical framework of the study. Several factors are assumed to affect an importer's purchasing decisions. Price of the product is an obvious and often the most important factor. There are also other factors such as qualitative characteristics (delivery time, reliability of supplies, packaging, brand names) and established relationships (e.g. cultural, historical or political ties between trading partners) affecting the trade flows of commodities. This leads to a presumption that importers differentiate between commodities by place of production. In dealing with China's demand for agricultural imports, it seems appropriate to adopt a theoretical framework, in which products are distinguished by their place of production and are not considered perfect substitutes for each other (product differentiation).

The estimation of the demand structures is therefore derived from the Armington's (1969) model, where it is assumed that the same goods of different origins are imperfect substitutes within an importing country's commodity market. In the model, the importing decision is split into two stages. At the first stage, the importer decides how much of the imported product to consume against all other goods. The decision is based on importer's income and price of the good. At the second stage, the importer decides how much of the product to purchase from alternative suppliers. The decision is based on total expenditure of the product and relative prices between the suppliers.

Now that the assumptions are in place, it is straightforward to derive the importer's overall demand equation, representing a country's $j$ imports $(M)$ as a function of economic activity $(Y)$ and real price of the good imported $(P / D)$,

$$
M_{j}^{d}=k_{1} Y_{j}\left(\frac{P_{j}}{D_{j}}\right)^{\epsilon_{m}^{p}}
$$

where $k_{1}$ is a constant with expected sign $k_{1}>0 ; D$ is the deflator; and $\epsilon_{m}^{p}$ is the price elasticity of import demand for good $M$. The income elasticity is equal to unity, a hypothesis that will later be tested.

Once the level of expenditures $Y_{j}$ for the imported product $M$ has been determined, the solution to the utility maximisation problem of how much of the product to purchase from alternative suppliers - let say an exporter of interest $i$ and its competitors $k$, which refer each of the $n-1$ other foreign supplying countries, to market $j$ whose corresponding export prices are $P_{i j}$ and $P_{k j}$ - may be expressed as

$$
X_{i j}^{d}=k_{2} M_{j}\left(\frac{P_{i j}}{P_{j}}\right)^{\epsilon_{x}^{p}}
$$

where $X_{i j}^{d}$ is the quantity of the product exported from country $i$ to country $j, k_{2}$ is a constant; $P_{i j}$ is the price of the good imported from country $i$ to country $j ; P_{j}$ is the average price of the product imported to country $j$; and $\epsilon_{x}^{p}$ is the relative-price elasticity of export demand. Product differentiation in equation (2) is reflected in the ability of exporters to influence the demand for their exports through relative-price changes. 
The methodological challenge of the study is to combine the theoretical framework with applied econometrics in order to provide a good representation of China's import demand for agricultural products. Empirical analysis of the study is based on econometric models with recently developed econometric concepts that capture the dynamics underlying China's import demand for agricultural products. Long-run elasticities of Chinese import demand for agricultural products are of particular interest. However, estimating such long-run relationships is challenging because the variables - such as income, the price level, trade flows, and exchange rates - used in the analysis typically exhibit multicollinearity and non-stationarity. ${ }^{1}$ Therefore, econometric modelling in the study is based on methods, which explicitly take these features of the data into account, namely co-integration techniques and error-correction model (ECM). There are two main advantages in using the cointegration techniques and ECM. First, it is possible to clearly distinguish between short-run and longrun effects. Second, the speed of adjustment toward the long-run equilibrium can be directly estimated.

The empirical analysis of the study will be conducted with a sample of annual data that cover China's agricultural imports from the EU and the rest-of-world for selected products from 1986 to 2005. To keep the task manageable, econometric analysis is restricted to six agricultural products: frozen pigmeat, frozen fish, whey, barley, beer, and wine. These products represented on average about 23 per cent of China's total agricultural imports from the EU. Volume and value data on trade flows over the period 1986 to 2005 are obtained from FAOSTAT (2007). Volume data is compiled in metric tons, and value data in thousands of euros. The transaction value is the value at which goods were sold by the exporter at the frontier of the exporting country [free-on-board (fob) valuation]. The unit prices of China's imports $\left(P_{C}\right)$, and unit prices of exports by the EU $\left(P_{E U}\right)$, are derived by dividing value by volume. The gross domestic product (GDP) index and the consumer price index $(\mathrm{CPI})$ are used as a measure of economic activity $\left(Y_{C}\right)$ and price deflator $\left(D_{C}\right)$ of China, respectively. The source of the data is the Economic Research Service of the United States Department of Agriculture (USDA 2007).

\section{Results}

\section{The responsiveness of China's agricultural imports to income changes}

The short-run and long-run responsiveness of Chinese agricultural imports to changes in incomes and absolute prices are summarised in Table 1. The estimated equations of import demand show, as expected, that income is statistically significant in explaining the level of demand for agricultural imports in China. The findings are consistent with earlier studies: Mohd. Yusoff and Salleh (1987), Lord (1991), and among others, have shown that income is an important factor in determining the import demand for agricultural products. The estimated long-run income elasticities of import demand range from clearly less than unity $(0.5)$ for beer to 3.0 for wine. The results suggest that a $1 \%$ increase in income level would increase beer imports by only $0.5 \%$, but wine imports would increase by $3 \%$ (6 times more than beer imports). The large differences in income elasticities have important implications for EU exporters. Wine exports have a considerably stronger growth potential in China than other products because of a strong response from consumers in China due to improvement in their real incomes. At the same token, wine exports will also be susceptible to larger swings of demand during business cycles. The results suggest that a $1 \%$ decrease in income level would eventually decrease wine imports by $3 \%$.

The adjustment of import demand from one level of income to another is determined by the error correction term. For example, the coefficients of the error correction terms in the import demand relationships are close to unity in absolute terms for barley, frozen pigmeat, whey and wine. This fact

\footnotetext{
${ }^{1}$ If this is the case, the conventional hypotheses-testing procedures based either on small sample or asymptotic distributions of the estimates (based on t, F, chi-square tests, and the like) may be in suspect. The problems are often dealt with by taking first differences of all the variables before any estimation are done. Nonetheless, taking first differences is a major drawback because the long-run variation of the data is removed, and only short-run effects are explained by the model.
} 
reflects the relatively quick response of Chinese importers to changes in income and prices, i.e. it does not take a great deal of time for import demand to resume its long-term equilibrium growth path when a short-run disequilibrium arises between import demand and income. In the case of beer and frozen fish, the situation is slightly different. The error correction term in the import demand relationship is clearly less than unity $(-0.35$ and -0.37$)$ in absolute terms. This fact reflects the relatively slow response of beer and frozen fish importers in China to changes in income and prices.

Table 1. Short-run and long-run elasticities of import demand in China for selected food products.

\begin{tabular}{lcccc}
\hline Commodity & \multicolumn{2}{c}{ Income elasticity } & \multicolumn{2}{c}{ Price elasticity } \\
& Short-run & Long-run & Short-run & Long-run \\
\hline Frozen Pigmeat & 1.77 & 1.65 & -0.07 & -0.39 \\
Frozen Fish & 0.17 & 1.49 & -0.09 & -0.26 \\
Whey & - & 1.00 & -0.04 & -0.14 \\
Barley & 0.39 & 0.98 & -0.11 & -0.07 \\
Beer & - & 0.47 & -0.43 & -0.47 \\
Wine & 1.50 & 3.04 & -0.30 & -0.80 \\
\hline
\end{tabular}

\section{The responsiveness of China's agricultural imports to price changes}

Examination of the price elasticities confirm the expectation that demand for Chinese agricultural imports is relatively inelastic with respect to price. Among the products listed in Table 1, five out of six products have elasticities less than 0.5 in the long-run. Barley has the lowest long-run price elasticity (气-0.1). This result suggests that on average a $1 \%$ decrease (increase) in the real price of barley would increase (decrease) imports of barley by only $0.1 \%$ in the long-run. Wine has the largest long-run import price elasticity (气-0.8). The policy implication of these low price elasticities is that exchange rate policies and commercial policy intervention measures in the form of tariff barriers to trade would not be very effective in changing the quantity of imports demanded.

The effects of a reduction in imports tariffs under China's WTO commitments are summarised in Table 2, from which a number of points can be made. The reductions in tariffs have had a pricedecreasing effect on the Chinese import market. As a result, an increase in China's imports has taken place. Imports of frozen pigmeat and frozen fish have increased $14 \%$ and $83 \%$, respectively, during the period from 2000 to 2005 . However, according to our modelling results, the contribution of tariff reductions for these increased volumes of imports has been very small, $1.8 \%$ and $0.5 \%$, respectively. Relatively low tariff cuts as well as low price elasticities of these products have resulted only very minor changes in import volumes. Most of China's increased appetite for imported pigmeat and fish has been fuelled by rapid income growth and increased trade.

In the case of beer and wine imports, tariff reductions explain part of the increase in China's import volumes. Our modelling results suggest that China has increased its wine imports by $33 \%$ due to tariff reductions, which is responsible for half of the total increase in import volume $(63 \%)$ for wine from 2000 to 2005 . The case is similar for beer, where tariff reductions accounts for about $18 \%$ increase in total imports; and China's total import of beer increase by 23\% from 2000 to 2005.

Table 2. Percentage changes in prices and volumes imported into China due to WTO tariff reductions for selected food products.

\begin{tabular}{lcccccc}
\hline Commodity & Import price & \multicolumn{2}{c}{ Import volume } & \multicolumn{3}{c}{ Number of years } \\
& & Initial effect & Long-term effect & $75 \%$ & $90 \%$ & $99 \%$ \\
\hline Frozen Pigmeat & -4.6 & 0.3 & 1.8 & 1 & 1 & 4 \\
Frozen Fish & -5.7 & 0.1 & 0.5 & 1 & 4 & 6 \\
Whey & 0 & 0 & 0 & - & - & - \\
Barley & 0 & 0 & 0 & - & - & - \\
Beer & -29.6 & 16.3 & 17.8 & 3 & 5 & 7 \\
Wine & -23.1 & 10.7 & 33.1 & 0 & 1 & 2 \\
\hline
\end{tabular}


Since tariff reductions take several years to have a full impact on import demand, the effect would continue even after the tariff reductions have taken place. The estimations demonstrate the extent of the time lag between the initial reduction in import prices after tariff reduction and the time required for imports to adjust fully to the new price level in the Chinese market. Imports of frozen pigmeat and wine respond relatively quickly to changes in prices. In the case of wine, 90 per cent of the adjustments occur within one year after the tariff reductions have taken place. The case is similar for pigmeat, where it takes only one year to adjust to 90 per cent of the new import level (equilibrium). However, imports of beer and frozen fish react slower to price changes, a characteristic that is reflected in the lower coefficient level of the error-correcting term (clearly less than unity). More specifically, it takes four years for frozen fish imports, and five years for beer imports to adjust to 90 per cent of the new import level (equilibrium). Hence, the impact of tariff reductions is faster on food products such as wine and frozen pigmeat, and the exporters should react quickly to the increase in demand for these products.

\section{China's demand for EU agricultural exports}

The estimations indicate that relative price movements affect significantly China's demand for EU exports, implying that EU's market share is influenced by price competitiveness (Table 3). In other words, EU exporters confront a downward-sloping demand schedule in China. For the combined agricultural exports of the selected EU products, the trade-weighted average price elasticity for China's import demand from the EU (which is equivalent to the elasticity of substitution for market share in China) is equal to -3.5 in the long run. This indicates that China's import demand for the selected EU agricultural products will increase by $3.5 \%$ on average if the relative prices of these products decrease by $1 \%$ on average.

Table 3. The short-run and long-run responsiveness of China's agricultural imports from the EU to changes in relative prices.

\begin{tabular}{lcccc}
\hline Product & \multicolumn{2}{c}{$\begin{array}{c}\text { Relative price elasticity of } \\
\text { export demand }\end{array}$} & \multicolumn{2}{c}{$\begin{array}{c}\text { EU's market share } \\
\text { in China (\%) }\end{array}$} \\
& Short-run & Long-run & $1995-1997$ & $2003-2005$ \\
\hline Frozen Pigmeat & - & -7.97 & 56.5 & 61.6 \\
Frozen Fish & -4.22 & -3.31 & 10.7 & 23.2 \\
Whey & -2.27 & -1.33 & 27.2 & 39.8 \\
Barley & -3.18 & -2.82 & 18.7 & 17.0 \\
Beer & -1.41 & -4.66 & 31.9 & 36.8 \\
Wine & -0.94 & -2.04 & 73.5 & 49.4 \\
\hline
\end{tabular}

Among the examined trade flows, the export of EU whey is the least sensitive to relative price changes, followed by wine exports. Whey and wine exports from the EU have relative-price coefficients of -1.3 and -2.0 , respectively. This indicates that China's import demand for EU whey will increase by only $1.3 \%$ if the relative price of whey decreases by $1 \%$. In contrast, the relative-price coefficient of the EU pigmeat exports is exceptionally large, -8.0. This indicates that China's import demand for EU pigmeat will increase by $8 \%$ if the relative price of pigmeat decreases by $1 \%$. The observed differences in relative-price coefficients by trade flow reflect the dynamic aspect of the Chinese agricultural trade, whereby trade flow rise and fall due to price competitions. Thus, price competition has the largest impact on frozen pigmeat and beer among the examined food products.

China's import demand from the EU generally takes several years to adjust to the relative-price change. China's imports of barley and frozen fish reflect quite quickly to changes in relative-prices. It takes only two years for China's barley imports from the EU to adjust to 90 per cent of the new import level (equilibrium). However, China's imports of beer and whey adjust slowly to the relative-price change, which is reflected in the near-zero coefficient of the error-correcting term. For example, it takes five years for China's beer imports from the EU and it takes four years for China's whey imports from the EU to adjust to 90 per cent of the new import level (equilibrium). Consequently, the impact of price competition is slower on food products such as beer and whey, and the exporters have more time to react to the increase in demand for these products. 


\section{Conclusions}

The results from the import price elasticities (Table 1) combined with the results from the relative price coefficients (Table 3) indicate that China's total agricultural imports on a product basis is insensitive to absolute price changes, but Chinese importers are sensitive to relative price changes on a product basis due to price competition among suppliers; once the expenditure for the imports of a product is determined, Chinese importers will seek for the cheaper products among the foreign suppliers. The results support the key findings of a study (DG Trade 2007b) by the European Commission that assesses market opportunities for EU companies in China: EU companies wanting to compete on price in the Chinese market will need to produce goods in China itself in order to be costcompetitive. Successful European companies are already diversifying into China-based manufacturing because they want to compete in the domestic Chinese market and not to produce for the export market. Good examples would be China-based manufacturing for European beer and meat processing for European slaughterhouses.

The results suggested that China's tariff reductions have been quite significant in changing the quantity of wine and beer exports from the EU to China. However, tariff reductions do not have an important role in changing the quantity of EU exports to China for the rest of the examined products. China's import demand analysis suggested that income growth effects play a dominant role in determining China's import demand for agricultural products, both in the short and long term. Rapid income growth has fuelled most of China's increased appetite for imported agricultural products. Strong economic growth is the major force behind the increasing buying power of the Chinese consumers. Continued growth in China's economy and huge domestic markets will fuel further export growth and opportunities for the EU.

\section{References}

Armington, P. (1969). A theory of demand for products distinguished by place of production, International Monetary Fund Staff Papers 16:159-178.

Colby, H, Price, J. and Tuan, F. (2000). China's WTO Accession Would Boost U.S. Ag Exports and Farm Income," Agricultural Outlook, Economic Research Service/USDA, AGO-269, March 2000.

DG Trade (2007a). New China study sees huge opportunities for EU exporters of green technology, high value goods and business services, 19 February 2007. Press Release, Directorate General for Trade, European Commission, Brussels.

DG Trade (2007b). Study on the Future Opportunities and Challenges in EU-China Trade and Investment Relations 2006-2010, 15 February 2007. China, Conferences and Studies, Directorate General for Trade, European Commission, Brussels.

FAOSTAT (2007). The detailed trade data of FAOSTAT, Food and Agricultural Organization of the United Nations (FAO). Updated date: June 30, 2007. Available at http://www.fao.org/site/406/default.aspx

Lord, M. (1991). Imperfect Competition and International Commodity Trade: Theory, Dynamics and Policy Modelling. Oxford University Press, New York. 403 p.

Mohd. Yusoff \& Salleh, M. B. (1987). The Elasticities of Supply and Demand for Malaysian Primary Commodity Exports. Malaysian Journal of Agricultural Economics 4: 59-72.

People's Daily (2006). EU agriculture exports to China to exceed 2 billion euros in five years. July 06, 2006, People's Daily Online. Available at http://english.people.com.cn/200607/05/ eng20060705_280369.html

Schmidhuber J. (2001). Changes in China's agricultural trade policy regime: Impacts on agricultural production, consumption, prices, and trade. China's Agriculture in the International Trading System, OECD,2001. pp: 21-49.

USDA (2007). China Agricultural and Economic Data: National Data, Economic Research Service, United States Department of Agriculture. Updated date: March 12, 2007. Available at http://www.ers.usda.gov/Data/ China/NationalForm.aspx. 